rations at present employed for the cure of ptosis are unsatisfaetory, sometimes producing too great, and sometimes too little result.

It is necessiry, in order to obtain perfect movement of the upper lid, to continne the action of the musculus frontalis to this lid itself. This ean be achieved by making a scar do the work of a tendon to the froutalis, by which means the upper lid is compelled to follow the movements of that muscle. The simplest way of doing this is to introduce a thick suture above the superciliary ridge, bringing it out at the margin of the lid, and to tie the ends together, leaving it gradually to cut its way out. It is possible also to apply the suture subcutaneously, thus avoiding all disfigurement by sears.

The cieatrix thus formed, acts as a tendon to the frontalis, raises the upper lid, and docs not prevent its closure.

Many eases have alrearly been operated on by the author with the happiest results.

\title{
Action of Foreign Bodies introduced into the Interior of the Eyeball.
}

Prof. TI. LFB ER, of Göttingen, in a paper on this subject, read at the London Congress, maintained that : 1. Foreign bodies which are clean, and which exert no elemical aetion, do not cause any inflammation in the interior of the eye.

2. Clean fragments of oxidizable metals-e. g., iron, steel, copper-do not eause purulent inflammation, but many other plienomena whieh seriously eompromise the funetions of the eye, especially eontraction of the vitreous and detachment and atrophy of the retina.

3. The entranee of metallic fragments into the interior of the human eje is usually followed by purulent inflammation, just as in experiments made without antiseptic precautions upon animals. This inflammation is always due to the action of germs which have entered througl the wound.

4. Certilin chemical substances-e.g., arsenie, binoxidle of mereury, eroton oil, ete.-when introdueed into the interior of the eye are capable of setting up purulent inflammation, which is quite independent of the action of germs.

5. The extract of septic liquils, in which the germs have been killed by boiling, set up a transient inflammation when injected into the anterior ehamber or into the eorncal tissue. These experiments farour the hypothesis that the phlogogenic action of the germs depends on the production of chemical substanees which act on the vesscls.

6. Cysticerei may also set up purnlent inflammation in the eyeball, due perhaps to an irritating secretion from these cntozoa.

\section{A New Method of Examining and Numerically Expressing the Colour Perception.}

Dr. Ole BUld, of Christiania, at the London Congress, explainel his methot, which is based on producing the four principal colours of an equal intensity and sliade.

From among the different hues of these colours the author has, for blue, eliosen that which nixed with uneoloured light appears blue or colourless. A yellow, eomplementary to this blue, and of a like sliade and intensity, is then protuced. $A$ red and a green have been chosen, which at the periphery of the retina appear cither of their real colours, or colourless. Such a hue of this recl and green is then rhosen as to give, when mixed in equal parts, an indifferent gray, of the same shade as that given by the mixture of blue and yellow above referred to.

From these four colours, six fainter tints are derived by mixing up ou Maxwell's clisk, the single colour with uncoloured (gray) light of the same shate as 
that given by each pair of the two complementary colours mixed together. The relative intensity of thesc tints can be cxpressed by indicating the number of the degrees of the coloured scctor, namely, $40^{\circ}, 60^{\circ}, 80^{\circ}, 120^{\circ}, 160^{\circ}, 240^{\circ}$. These tints are fixed by imitating them with pigment, and then-together with the four principal colours--painted on a black plate in squares.

A patient's colour-sense may be examined by this plate simply by pointing out any coloured or uncoloured square, and then asking him to indicate that squarc which appcars most like it. If he is colour-blind, he will make mistakes. If his colour-sense is diminished by discase, both the kind and the degrec of the defect may be detcctcd. As the healthy eye at a distance of one metrc from the plite can just discern the faintest tint $-40^{\circ} \rightarrow \mathrm{a}$ colour-sense corrcsponding to this is taken as normal. If, e.g., a patient can discern red only up to $80^{\circ}$, and green to $120^{\circ}$, he is beginning to turn grcen-rcd-blind, and his perception of these colours may be expressed for the red by 400 and for the green by $400^{\circ}$

\section{MIDVIFERY AND GYNACOL.OGY.}

\section{Antisepsis in Midwifery.}

Prof. Spiegeibera, of Breslau, in a communication forwarled to the London Congress, sail that the great reform in surgery brought about by the antiseptic treatment could not fail to liave a deep influcnec upon the treatment of the complications in ehildbed, as it was well known long ago that the latter are the same which arise from wounds. If, lowever, scrupulous cleanliness, which had been advocated long agn, favoured a normal course of the puerperium, the practical gain was not very great.

The idea that the puerperal wounds are infected, and the inflummation of the genital organs are initiatcd by germs coming from outside, became more in vogue, and the idea that phlogogenous natter might be produced spontaneonsly within the genital tract, was almost abandoned. The consequence of this idea was recommending the most serupulous cleanliness of liands and iustruments ; forbirlding practitioncrs engaged in mid wifery to attend other patients; forbidding students engaged in dissecting to attend nidwifery cases; forbidding nurses attending eases of puerperal fever to attend normal cascs at the same time.

The experienec that all these measures relueed the number of bad cases only little originated the idea of secondary antiscpsis. Intra-utcrine irrigations ami drainage camc in use, but without much avail; the opinion took root that there was no identity between wound and childbed complications-that there existed an essential puerperal process.

Thesc failures can be made comprchensible by laying clearly open the development of infcction; and lere, too, is it necessary to refer to the history of the antiseptic surgery.

The thcory and practice of Lister's systcm is founded upon the vicw now sufficicntly justified by expcricnce, that infection is brought about by the action of germs which float about in the surroundings of the patient, and which fall on the recently-made wound. It is, therefore, absolutcly necessary to clean the surroundings froun the germs; if that is not practicable, to destroy the cfliciency of these germs while the wound is open, and by keeping subsequently the wound closed. 'The application of these rules upon the pucrperium means: The strictest cleanliness and antiscpsis during the time in which the puerperal wound arises-that is, during birth_-as well from the part of the persons attending the mother as firom the mother herself. Prevention of air entering the genital tract; and as thit is 